\title{
How the COVID-19 pandemic has prevented children with cancer from pursuing their schooling in hospital or at home
}

\author{
Annarita Adduci ${ }^{1} \cdot$ Andrea Ferrari $^{1}$ (i) $\cdot$ Paolo Grampa $^{1} \cdot$ Monica Giovanetti ${ }^{1} \cdot$ Maura Massimino $^{1}$
}

Received: 11 December 2020 / Accepted: 20 December 2020 / Published online: 12 January 2021

(C) The Author(s), under exclusive licence to Springer-Verlag GmbH, DE part of Springer Nature 2021

\section{Dear Editor:}

Children and adolescents with cancer unavoidably experience disruptions in their daily lives, which often involve them having to stay away from people and places that are emotionally important to them, including school. The often-protracted treatment of their disease strongly limits their school attendance, and this gives rise not only to critical issues with their acquisition of knowledge and skills but also to important psychological, relational, and social problems [1].

Oncologists and psychologists recommend that patients continue to attend school while receiving cancer treatments whenever possible and compatible with their clinical condition. This can be very important to preserving a patient's sense of normality, ensuring a continuity with their past, and an opportunity to make plans for their future, as well as countering their risk of social withdrawal [1].

When hospital stays, logistic issues or a patient's clinical condition makes it is impossible to go to school, then schooling in hospital or at home becomes fundamentally important. In Italy, schooling is available in hospitals as a public service, under specific arrangements between schools for all age groups and hospital administrations. Schooling services at home are organized locally and provided by teachers from patients' own schools (Table 1).

The COVID-19 pandemic has led to lockdowns as drastic measures to contain the coronavirus's spread, with a very heavy impact on social life generally, and in the sphere of education in particular $[2,3]$. School closures have meant that children with cancer have also lost the chance to continue their lessons in hospital or at home-a situation justified by the

Andrea Ferrari

andrea.ferrari@istitutotumori.mi.it

1 Pediatric Oncology Unit, Fondazione IRCCS Istituto Nazionale dei Tumori, Via G. Venezian, 1, 20133 Milan, Italy need to protect their health. Like all other students, those with cancer have been offered access to remote classrooms. But distance learning cannot meet the specific needs of such particular students as children and adolescents with cancer. For them, the guidance that teachers attending in person can offer - as emotionally separate, neutral figures outside a patient's family - plays a crucial part in motivating patients to invest in their studies and their future. It helps them to combat a tendency (often prompted by their disease) for them to become detached and lose interest [4].

Italy's Ministry for Education decided that operators who could be defined more specifically as providing "healthcare" (such as psychologists and social workers) could continue to do so during the pandemic, but teachers could not. The educational activities normally organized by the Local Authorities in Milan (with educators normally present on the ward) were suspended as well. This situation in Italy has not changed since March 2020. Both before and during the second wave of the pandemic in late 2020, pediatric cancer patients continued to go without the fundamental support of the schooling services normally provided in hospital and at home.

Denying these patients the chance to continue their schooling can have very severe psychological consequences. For a start, it compounds the effect of their parents' tendency to be overprotective because of their child's disease. Parents experience a heavy sense of vulnerability, and their fears concerning their child's cancer are exacerbated by their worries about the viral disease. This leads to a risk of parents tending to isolate their nuclear family, staying away from their wider network of family and friends. This dysfunctional mechanism is amplified by the restrictions necessitated by COVID-19 and also applies to their child's schooling [4].

There is also the risk of parents tending to disinvest in their child's education and future. Uncertainty about their prognosis and the need to concentrate on the treatment of their disease can lead to any plans for the child's future being abandoned. Continuing their education, in the classroom or in hospital, can help to combat this harmful tendency. 
Table 1 The experience at the Pediatric Oncology Unit of the Istituto Nazionale dei Tumori, in Milan, concerning schooling services in hospital or at home

\begin{tabular}{lllll}
\hline & & Academic year 2016-2017 & Academic year 2017-2018 & Academic year 2018-2019 \\
\hline In-hospital school services & Primary-school age & 31 & 26 & 21 \\
& Lower secondary school & 20 & 25 & 18 \\
& Higher secondary school & 21 & 22 & 24 \\
& Total no. of patients & 72 & 73 & 63 \\
Schooling services at home & No. of patients & 13 & 12 & 15 \\
\hline
\end{tabular}

To this picture of hyper-protectionism and disinvestment, the situation deriving from the COVID-19 pandemic has added the further damage caused by the loss of any inhospital schooling resources $[4,5]$.

It is hard to strike the right balance between institutions struggling to establish a set of rules to ensure the safety of school service operators, the need for clinical precautions, and the need to find some way to resume activities that are fundamentally important to our patients. After much debate proved of little use, we embarked on a campaign to raise awareness of the issue in the mass media and social media, with the support of our parents' associations (Fig. 1). This action mobilized a remarkable collective interest in the problem and led to the end of the stalemate in the decision-making process. The various organizations involved took action and schooling activities resumed for pediatric patients in hospital and at home. At the time of this report, schools were still closed in many parts of Italy for all except primary-school students, and secondary-school students were only attending classes online.

While the authors remain fully aware of the enormous social difficulties posed by the COVID-19 pandemic, this story aims to emphasize the importance of finding special solutions for particular categories, such as children and adolescents with cancer. It also underscores the importance of schooling, not only for a child's education and development but also and especially as a space for care and a time for living.

\section{Compliance with ethical standards}

Conflict of interest The authors declare that there is no conflict of interest.

\section{References}

1. Eiser C, Vance YH (2002) Implications of cancer for school attendance and behavior. Med Pediatr Oncol 38:317-319

2. Clerici CA, Massimino M, Ferrari A (2020) On the clinical psychologist's role in the time of COVID-19, with particular reference to experience gained in pediatric oncology. Psychooncology. 29:13741376. https://doi.org/10.1002/pon.5418

3. Casanova $\mathrm{M}$ et al (2020) How young patients with cancer perceive the Covid-19 epidemic in Milan, Italy: is there room for other fears? Pediatric Blood Cancer 67(7)

4. Darlington AE, Morgan JE, Wagland R et al (2020) COVID-19 and children with cancer: parents' experiences, anxieties and support needs. Pediatr Blood Cancer 21:e28790. https://doi.org/10.1002/ pbc.28790 Online ahead of print

5. Dooley DG, Simpson JN, Beers NS (2020) Returning to school in the era of COVID-19. JAMA Pediatr. https://doi.org/10.1001/ jamapediatrics.2020.3874. Online ahead of print

Publisher's note Springer Nature remains neutral with regard to jurisdictional claims in published maps and institutional affiliations.
Fig. 1 A title of an Italian newspaper talking about the school denied for pediatric oncology patients, after the campaign to raise awareness activated by parents' associations
HOME , MILANO , CRONACA

Pubblicato il 3 ottobre 2020

\section{Milano, niente scuola per i bambini in cura: "Lezioni sospese da febbraio"}

Si tratta dei ricoverati al reparto pediatrico dell'Istituto Nazionale dei Tumori. La denuncia dei genitori: "Sono sparitj tutti" 